\title{
Enhancement and Optimization Mechanisms of Biogas Production for Rural Household Energy in Developing Countries: A review
}

\author{
Yitayal Addis Alemayehu*
}

Department of Environmental science; Faculty of natural and computational sciences; Kotebe University College, Addis Ababa, Ethiopia

\begin{abstract}
Anaerobic digestion is common but vital process used for biogas and fertilizer production as well as one method for waste treatment. The process is currently used in developing countries primarily for biogas production in the household level of rural people. The aim of this review is to indicate possible ways of including rural households who own less than four heads of cattle for the biogas programs in developing countries. The review provides different research out puts on using biogas substrates other than cow dung or its mix through different enhancement and optimization mechanisms. Many biodegradable materials have been studied for alternative methane production. Therefore, these substrates could be used for production by addressing the optimum conditions for each factor and each processes for enhanced and optimized biogas production.
\end{abstract}

Keywords: biogas, digestion, factor, process, substrate

Article History: Received June 15, 2015; Received in revised form August 26, 2015; Accepted October 10, 2015; Available online How to Cite This Article: Alemayehu, Y.A. (2015) Enhancement and Optimization Mechanisms of Biogas Production for Rural Household Energy in Developing Countries: A review, Int. Journal of Renewable Energy Development ,4(3), 189-196. http://dx.doi.org/10.14710/ijred.4.3.189-196

\section{Introduction}

One requirement for sustainable development is the availability of adequate energy services for satisfying basic needs, improving social welfare, and achieving economic development (Rogner et al. 2004). Consequently, the challenge of energy for sustainable development will require uninterrupted effort on the part of international organizations, national governments, the energy community, civil society, the private sector and individuals (Green et al. 2004).

The energy consumption patterns of the people in developing countries tend to add to their misery and aggravate their poverty. Therefore, a direct improvement in energy services would allow these people to enjoy both short-term and long-term advances in living standards through advancing their energy strategies based on increasing the use of energy carriers other than biomass, or on using biomass in modern ways (Reddy et al. 2004). This is to mean that turning solid biomass to liquid and gas by efficient and greener technologies is essential in order to minimize environmental pollution, land degradation and social welfare.

In many developing countries women and children, who do most of the domestic labor in many cultures, spend more and more hours searching for wood for fuel. In some places, it takes eight hours, or more, just to walk and back with a load of twigs and branches that will only last a few days. For people who live in cities, the opportunity to scavenge fire wood is generally non-existent and fuel must be bought from the market which is too expensive. In Addis Ababa, Ethiopia, for example, 25\% of households' income is spent on wood for cooking (Cunningham et al. 2003).

In addition, people often dry and burn animal manure as an additional source of household energy. When cow dung is burned in open fires, more than 90 percent of the potential heat and most of the nutrients are lost compared to the efficiency of using dung to produce methane gas which is an excellent fuel (Cunningham et al. 2003). Use of these traditional fuels in cooking stoves with efficiency as low as 10 to 12

${ }^{*}$ Corresponding author: +251-922985324

E-mail: yituaddis@gmail.com 
Citation: Alemayehu, Y.A. (2015) Enhancement and Optimization Mechanisms of Biogas Production for Rural Household Energy in Developing Countries: A review, Int. Journal of Renewable Energy Development ,4(3), 189-196, http://dx.doi.org/10.14710/ijred.4.3.189-196

$\mathrm{P}$ a g e 190

percent exacerbate the exposure of people to indoor pollution (Chipman and Dizioubinski 1999).

To prepare for a transition to more sustainable sources of energy, viable alternatives for conservation, supplementation, and replacement must be explored. One of these is bio-fuel production from agricultural, municipal, and industrial wastes which is efficiently accomplished through conversion to biogas, a mixture of mostly methane $\left(\mathrm{CH}_{4}\right)$ and carbon dioxide $\left(\mathrm{CO}_{2}\right)$, via anaerobic digestion. In practice, microbial anaerobic conversion to methane is a process for effective waste treatment, biological fertilizer and sustainable energy production. It has the potential for reducing the use of traditional biomass, the demand for fossil fuels like coal, oil, and natural gas which continued exploitation will significantly impact our environment and affect the global climate (Wilkie 2008).

Accordingly, developing countries in collaboration with the Netherland Development Organization (SNV) have embarked on biogas programs in developing countries so as to address the rural energy crisis and indoor pollution caused by the burning of traditional biomass (Anonymous 2011). However, the production potential is restricted as different factors have yet not been critically considered, and focus has been given only for a single substrate, manure which has lower energy content than green shrubs since animals that produce it have already digested the substrate (Gannon 2005; Marshal 2010). In addition, the program has an exclusive nature as it only considers those who possess more than four heads of cattle (Getachew et al. 2006). These together make little attainment of objective of biogas technology dissemination programs as there could be minimum substitution of solid biomass to gaseous one so that the health and environmental impacts would not be progressed as intended and expected.

The purpose of this review is therefore to assess potential substrates that could be used for biogas production so that non-biogas users would be included in the program, and users would produce relatively more biogas using additional substrates together with cow dung. In addition, this paper intended to review and indicate favorable conditions for optimum gas production from mixed substrates. Moreover, it would forward enhancement mechanisms for more gas production.

\section{Rationale of using biogas than solid Biomass}

Physical form and contaminant content are the two characteristics of fuels that most affect their pollutant emissions when burned. It is generally difficult to pre-mix solid fuels sufficiently with air to assure good combustion in simple small-scale devices such as household stoves. Even though most biomass fuels contain few noxious contaminants, they are usually burned incompletely in household stoves and so produce a wide range of health-damaging pollutants (Mckinney and Schoch 2003).

Biomass burning is a major contributor to air pollution and the green house gas effect when done unsustainably (i.e. when replacements are not planted for all the materials burned). It can emit carbon monoxide, nitrogen oxides $\left(\mathrm{NO}_{\mathrm{X}}\right)$, and particulate matter (such as ash and soot) into the air (Botkin and Keller 1995). Burning municipal solid waste can also be extremely dangerous from this perspective, potentially releasing known carcinogens and heavy metals into the environment. However, such emissions from bio-fuels are less than those produced from comparable fossil fuels (Mckinney and Schoch 2003). For example, wood burning contributes less to acid precipitation than coal. Because wood has little sulfur, it produces few sulfur gases and burns at lower temperatures than coal; thus it produces fewer sulfur oxides (Cunningham et al. 2003). Two billion people, about $40 \%$ of the total world population, depend on fire wood and charcoal as their primary energy source. Of these people, three-quarters (1.5 billion) do not have an adequate and affordable supply. Most of them are in the less developed countries where they face a daily struggle to find enough fuel to warm their homes and cook their food. The problem is intensifying because rapidly growing populations in many developing countries create increasing demands for fire wood and charcoal from a diminishing supply (Cunningham et al. 2003). Each person in Ethiopia, Tanzania and Gambia (Africa) and in Thailand (south eastern Asia) uses more than a ton of wood each year and that nearly everyone in these countries is completely dependent on wood for energy (Karen A. 1994; Ethiopia's Energy Sector 2010).

All in all, the efficiency and the environmental concerns of energy use can be progressed in one of the strategies forwarded by UNDP (2004) i.e. the 'energy ladder'. It is a framework for examining trends and impacts of household fuel use and ranks these fuels along a spectrum running from simple biomass fuels (dung, crop residues, wood) through fossil fuels (kerosene and gas) to the most modern form (electricity). The energy assessment further elaborated that the fuel-stove combinations that represent rungs in the ladder tend to become cleaner, more efficient, more storable, and more controllable in moving up the ladder. Biogas, produced through anaerobic digestion, provides both fuel and fertilizer, while options on biomass uses without anaerobic digestion (burning, applying on a field, applying to a field and ploughing under, and composting) provide either one or the other, but not both (Wilkie 2008). Nitrogen can be lost during digestion only by reduction of nitrates to nitrogen gas and volatilization of ammonia into biogas. Since organic matter is degraded during digestion to produce biogas, the percentage of nitrogen in the slurry rises, compared with solid content. Nitrogen is conserved during anaerobic digestion i.e. a reduction in total solids 
concentration is accompanied by a corresponding increase in the nitrogen content of the remaining solids which is not observed in an aerobic use of biomass (Marchaim 1992).

In addition to creating clean-burning energy, anaerobic digestion also eliminates harmful pathogens and odors, and most importantly, the biogas process produces high-quality, nitrogen-rich fertilizer that can be used to replace chemical fertilizers made with fossil fuels. Unlike compost, biogas slurry is a liquid and can be applied on a commercial scale with existing farm equipment. The fertilizer replacement value of biogas slurry far exceeds any potential revenue from the gas itself (Weisman 2009). For example, a study on the effect of biogas slurry in crop yield shows increment yield of $13.6 \%$ for wheat, $25 \%$ for vegetables (Karki et al. 1995 cited in Gurung 1997), and $18 \%$ for maize and cotton (Gurung 1997).

\section{Optimization Level}

Marshal (2004), Jemmett (2006) and (Rahmat et al. 2014) reported that depending on the digestion process, the methane content of biogas is generally between $55-80 \%$. The remaining composition is primarily $\mathrm{CO}_{2}$ with trace quantities (0-15000 ppm) of corrosive $\mathrm{H}_{2} \mathrm{~S}$ and $\mathrm{H}_{2} \mathrm{O}$. In general, it would be best and clean if the methane content is above $75 \%$ by absorbing the $\mathrm{CO}_{2}$ with lime and $\mathrm{H}_{2} \mathrm{~S}$ by lead acetate (see equations 7 and 8). Together with ignition test, the gas characteristics should be tested, evaluated and optimized according to Table 1 after production.

Table 1

\begin{tabular}{ll} 
Biogas Characteristics & \\
\hline Characteristic & Value/Behavior \\
\hline Density & $1.2 \mathrm{~kg} / \mathrm{m}^{3}$ \\
Calorific Value & $4-7.5 \mathrm{kwh} / \mathrm{m}^{3}$ \\
Ignition temperature & $700^{\circ} \mathrm{C}$ \\
Ignition concentration gas content & $6-12 \%$ \\
Smell & Rotten eggs \\
\hline \multicolumn{2}{c}{ Source: EEMBPM 2002; Sidhu 2006 }
\end{tabular}

\section{Enhancing the biochemical processes in anaerobic digestion}

In anaerobic digestion there are four stages: hydrolysis, acidification, acetogenesis and methane production (Sagagi et al. 2009; Rai 2004). Different microorganisms play a significant role in each stage of the processes. Therefore, intervention and follow up in all the stages is essential for enhanced and optimum methane production.

\subsection{Enzymatic hydrolysis}

Enzymatic hydrolysis is the process where the fats, starches and proteins contained in cellulosic biomass are broken down into simple compounds (Rai 2004). Polymers are transformed into soluble monomers through enzymatic hydrolysis.

$$
\left(C_{6} I_{10} O_{5}\right)_{n}+n I_{2} O \stackrel{\text { Hydrolysis }}{\longrightarrow} n\left(C_{6} H_{12} O_{6}\right)
$$

These monomers become substrates for the microorganisms in the second stage where they are converted in to organic acids by a group of bacteria (Sagagi et al. 2009). This process is natural, but could be enhanced by external application of enzymes for better methane production. For example, the hydrolysis of cellulose and hemi-cellulose is considerably enhanced by the application of hydrolytic enzymes of fungal origin on selected substrates, and increases methane yield (Quinones 2010).

\subsection{Acid formation (Acidogenesis)}

It is a process where microorganisms of facultative and anaerobic group, collectively called as acid formers, hydrolyze and ferment compounds into acids and volatile solids. As a result, complex organic compounds are broken down to short chemical simple organic acids. In some cases, these acids may be produced in such large quantities that the $\mathrm{pH}$ may be lowered to a level where all biological activity is arrested. This initial acid phase of digestion may last about two weeks and during this period a large amount of carbon dioxide is given off (Rai 2004). In this stage, there should be intervention in buffering the contents of the digester as the micro-organisms may be affected irreversibly. Generally, if $\mathrm{pH}$ is below 4.5 in the acidogenesis phase, there is a need of adding adjusting substances like lime, ash or ammonia as the gas producing bacteria couldn't ferment the acid and restore balance as reported by Saxon (1998).

\subsection{Acetogenesis}

Simple molecules created through the acidogenesis phase are further digested by acetogens to produce largely acetic acid as well as carbon dioxide and hydrogen (Buswell and Sollo 1948). Acetogen are the vital link between hydrolysis, acidogenesis and the methanogenesis in anaerobic digestion. Acetogenesis provides the two main substrates for the last step in the methanogenic conversion of organic material, namely hydrogen and acetate. Both the acidogenesis and acetogenesis produce the methanogenic substrates, acetate, $\mathrm{H}_{2}$ and $\mathrm{CO}_{2}$ (Chynoweth and Isaacson 1987).

$$
n\left(\mathrm{C}_{6} \mathrm{H}_{12} \mathrm{O}_{6}\right) \stackrel{\text { Acetogenesis pratogenesis }}{\longrightarrow} n\left(\mathrm{CH}_{3} \mathrm{COOH}\right)
$$

\subsection{Methane formation (Methanogenesis)}

Organic acids as formed above are then converted into methane $\left(\mathrm{CH}_{4}\right)$ and $\mathrm{CO}_{2}$ by the bacteria which are strictly anaerobes, called methane fermenters (Rai 2004;). In this step, methanogenic bacteria generate methane by two routes, by fermenting acetic 
Citation: Alemayehu, Y.A. (2015) Enhancement and Optimization Mechanisms of Biogas Production for Rural Household Energy in Developing Countries: A review, Int. Journal of Renewable Energy Development ,4(3), 189-196, http://dx.doi.org/10.14710/ijred.4.3.189-196

$\mathrm{P}$ a g e 192

acid to methane $\left(\mathrm{CH}_{4}\right)$ and $\mathrm{CO}_{2}$ and by reducing $\mathrm{CO}_{2}$ via hydrogen gas or by other bacterial species.

$$
\begin{aligned}
& \mathrm{CH}_{3} \mathrm{COOH} \stackrel{\text { Metane forming bacteria }}{\longrightarrow} \mathrm{CH}_{4}+\mathrm{CO}_{2} \\
& \mathrm{CO}_{2}+4 \mathrm{H}_{2} \stackrel{\text { Reduction }}{\longrightarrow} \mathrm{CH}_{4}+2 \mathrm{H}_{2} \mathrm{O}
\end{aligned}
$$

Similarly, $\mathrm{CO}_{2}$ can be hydrolyzed to carbonic acid and to methane as in equations 5 and 6

$$
\begin{aligned}
& \mathrm{CO}_{2}+\mathrm{H}_{2} \mathrm{O} \stackrel{\text { Hydrolysis }}{\longrightarrow} \mathrm{H}_{2} \mathrm{CO}_{3} \\
& 4 \mathrm{H}_{2}+\mathrm{H}_{2} \mathrm{CO}_{3} \stackrel{\text { Reduction }}{\longrightarrow} \mathrm{CH}_{4}+3 \mathrm{H}_{2} \mathrm{O}
\end{aligned}
$$

The carbon dioxide and hydrogen sulfide in the biogas are undesirable. They are removed for optimum performance of biogas as fuel. Carbon dioxide is removed by passing the gas into lime water which turns milky due to formation of calcium carbonate.

$$
\mathrm{Ca}(\mathrm{OH})_{2}(\mathrm{aq})+\mathrm{CO}_{2}(\mathrm{~g}) \rightarrow \mathrm{CaCO}_{3}+\mathrm{H}_{2} \mathrm{O}
$$

$\mathrm{H}_{2} \mathrm{~S}$ is removed by passing the gas through a lead acetate solution (Sagagi et al. 2009).

$$
\begin{aligned}
& \left(\mathrm{CH}_{3} \mathrm{COO}\right)_{2} \mathrm{~Pb}(\mathrm{aq})+\mathrm{H}_{2} \mathrm{~S}(\mathrm{~g}) \rightarrow \mathrm{CH}_{3} \mathrm{COOH}(\mathrm{aq})+ \\
& \stackrel{\mathrm{PbS}(\mathrm{s})}{ }
\end{aligned}
$$

For efficient digestion, these acid formers and methane fermenters must remain in a state of dynamic equilibrium. This equilibrium is a very critical factor which decides the efficiency and rate of generation (Rai 2004).

\section{Enhancement of bio-digestion for optimum production}

Enhancing in each step of the different biochemical processes is essential for optimum biogas production. This could be done through selecting and adjusting the favorable conditions for the microorganisms that are used for the conversion in each process. The different factors that should be adjusted are reviewed as follows:

\subsection{Temperature}

Both fixed temperature at which bio-digestion take place and temperature fluctuation affect the quantity and quality of biogas production. For the former case, methane bacteria (methanogenes) work best at a temperature of $35-38{ }^{\circ} \mathrm{C}$ and fall in gas production starts at $20^{\circ} \mathrm{C}$ and stops at a temperature of 10 to $13{ }^{\circ} \mathrm{C}$ (Velsen et al. (1979); Dahlman and Forst (2001); Rai 2004)). In this connection, there are two significant temperature zones in anaerobic digestion and two types of microorganisms that should be considered, mesophilic and thermophilic. The optimum mesophilic temperature lies at about $35^{\circ} \mathrm{C}$, while the thermophilic temperature is around $55^{\circ} \mathrm{C}$. Most of the sewage digestion tanks are heated at $35{ }^{\circ} \mathrm{C}$ so as to reduce the time required for digestion and minimize the capacity of the tanks (Velsen et al., 1979; Rai 2004). Others reported that more biogas is produced at mesophilic temperature zones than at room temperature as shown in Table 2.

Table 2

Rate of biogas production from manures

\begin{tabular}{lll}
\hline \multirow{2}{*}{ Temperature } & $\begin{array}{l}\text { Manure } \\
\text { Type }\end{array}$ & $\begin{array}{l}\text { Rate (mL/hr/litre } \\
\text { of digester) }\end{array}$ \\
\hline \multirow{3}{*}{ Room } & Cow & 3 \\
& Chicken & 9 \\
& Pig & 1 \\
Mesophilic & Cow & 4 \\
& Chicken & 13 \\
Thermophilic & Pig & 2 \\
& Cow & 3 \\
& Pig & 1 \\
\hline
\end{tabular}

Source: Prasad 2012

Furthermore, since methanogenesis is sensitive to temperature fluctuations, effective insulation should be done during the digestion process. According to NRCS (2005), the daily fluctuations of digester temperature should be limited to less than $1{ }^{\circ} \mathrm{C}$. Bilhat (2008) reported that uninsulated bottles (biogas digesters) showed a change of temperature from 20.5 ${ }^{\circ} \mathrm{C}$ to $47{ }^{\circ} \mathrm{C}$ i.e. a $26.5^{\circ} \mathrm{C}$ rise. But, sand jacketed bottle temperature went from $20.5{ }^{\circ} \mathrm{C}$ to $23{ }^{\circ} \mathrm{C}$, a $2.5{ }^{\circ} \mathrm{C}$ rise at the same time when both were immersed in a $50{ }^{\circ} \mathrm{C}$ water bath and were stayed for 30 minutes and above. Therefore, insulating biogas digesters with concrete or bury it underground should be taken as a pr-requisite before the beginning of biogas production.

\section{$5.2 \mathrm{pH}$ or hydrogen ion concentration}

$\mathrm{pH}$ of slurry changes at various stages of digestion. In the initial acid formation stage, in the fermentation process, the $\mathrm{pH}$ is around 6 and much of $\mathrm{CO}_{2}$ is given off. In the latter 2-3 weeks time, the $\mathrm{pH}$ increases as the volatile acid and $\mathrm{N}_{2}$ compounds are digested and $\mathrm{CH}_{4}$ is produced. To maintain a constant supply of gas, it is necessary to maintain a suitable $\mathrm{pH}$ range in the digester. The digester is usually buffered to maintain the $\mathrm{pH}$ at 6.5 to 7.5 . In this $\mathrm{pH}$ range, the micro-organisms will be very active and bio-digestion will be very efficient (Rai 2004).

The introduction of too much raw material can cause excess acidity and the gas-producing bacteria will not be able to digest the acids quickly enough. The addition of a little ammonia can raise the $\mathrm{pH}$ value very fast. If the $\mathrm{pH}$ grows too high (not enough acid), fermentation will slow until the digestive process forms enough acidic carbon dioxide to restore balance (Saxon 1998). 


\subsection{Carbon to Nitrogen ratio of the input material}

Besides carbon the quantity of nitrogen present in the input material is a crucial factor in the production of biogas. The elements of carbon (in the form of carbohydrates) and nitrogen (as protein, ammonium nitrates) are the main food of anaerobic bacteria. Carbon is used for energy and nitrogen for building the cell structure. The bacteria use up carbon about 30 times faster than they use up nitrogen. So, carbon and nitrogen should be present in the proper proportion i.e. C: $\mathrm{N}$ is 30:1 (Rai 2004). If the ratio is higher, the nitrogen will be exhausted while there is still a supply of carbon left. This causes some bacteria to die, releasing the nitrogen in their cells and eventually restoring the equilibrium. Digestion proceeds slowly as this occurs. On the other hand, if there is too much nitrogen, fermentation (which will stop when the carbon is exhausted) will be incomplete and the "leftover" nitrogen will not be digested. This lowers the fertilizing value of the slurry (Saxon 1998). Hills (1979) reported that the greatest methane production per unit occurred when the C: $\mathrm{N}$ ratio of the feed was 25:1.

Such 25:1to $35: 1$ ratio could be maintained only when cow dung is supplemented and mixed with plant materials depending on the substrate used. According to Rai (2004), substituting a portion of vegetable waste instead of dung will enable to get more gas for the same amount of substrate. Moreover, most vegetable matter has a much higher $\mathrm{C} / \mathrm{N}$ ratio than dung has. As a result, the former produces about eight times as much biogas as manure, so some nitrogen producers (preferably organic) must generally be added to the vegetable matter (EEMBPM 2002). This could lead to a conclusion that plant materials are preferable substrates for biogas production to cow dung. Consequently, biogas programs are recommended to consider alternative feed stocks than entire dependence on a single one, cow dung.

\subsection{Total Solid (TS) and Volatile solid (VS) Content}

The cow dung is mixed usually in the proportion of $1: 1$ (by weight) in order to bring the total solid content to 8-10\%. The raw cow dung contains 80$82 \%$ of moisture. The balance $18-20 \%$ is termed as total solids. The adjustment of total solid content helps in bio-digesting the material at the faster rate, and also in deciding the mixing of the various crop residues, weeds, and plants etc. as feed stocks in biogas digester (Rai 2004).

Elias (2010) studied that the TS and moisture contents of fresh cow dung and VS (as percentage of TS) and ash content were $16 \%, 84 \%, 79.11 \%$ and $20.89 \%$, respectively. For cow dung, the TS was in the range of $15-20 \%$, and the TS and moisture contents (MC) of Cladodes were $14 \%$ and $86 \%$, respectively. Nallathambi et al. (1990) studied the biogas production potential of Parthenium in batch digester. They observed that the maximum gas production was 35 liters per $\mathrm{kg}$ fresh plant at a TS concentration of $5 \%$ and the methane content of the biogas was $75 \%$. Similarly, Steffen et al. (2000) reported that the composition of garden wastes, fruit wastes, food remain and typical animal's wastes consists of 50-70 \% of TS and VS is 70$90 \%$ of TS. For cow dung, the VS as percent of TS are in the range $75-80 \%$. Tesfaye (2007) studied that the TS and VS (as percentage of TS) of chat waste and found them to be $29 \%$ and $90 \%$, respectively. This is also evident that more biogas is produced from green biodegradable species and co-digestion with cow dung than cow dung alone.

\subsection{Retention time or rate of feeding}

The period of retention of the material for biogas generation depends on the type of feed stocks and the temperature (Rai 2004). Normal retention period is between 30 and 45 days and in some cases 60 days (Rai 2004). Depending on the waste material and operating temperature, a batch digester starts producing biogas after two to four weeks, slowly increasing in production then droping off after three or four months (Jemmett 2006). Here it should be noticed that gas may be produced before these periods. However, the gas produced could be other than methane majorly carbon dioxide. This can be checked by ignition test (Yitayal et al. 2011).

According to Gannon (2005), the amount of time the substrates spend in the digesters is one of the critical factors in methane production. Too short retention time means an inefficient extraction of methane, so full revenue is not realized. Too long retention time means too much is spent on surplus capacity or not enough substrate is being added to maximize revenue.

\subsection{Feed stocks and Co-digestion}

According to Wilkie (2008), the feed stocks for biogas generation can be composed of carbohydrates, lignocelluloses, proteins, fats or mixtures of these components.

Table 3.

Theoretical Methane yield

\begin{tabular}{lc}
\hline Component & Max. Methane Yield ( $\mathbf{m}^{\mathbf{3}} \mathbf{/ t}$ VS) \\
\hline Carbohydrate & 370 \\
Proteins (leucine) & 998 \\
Fats (lauric acid) & 585 \\
Plants & 470 \\
\hline \multicolumn{2}{c}{ Source: Wilkie (2008); EEMBPM (2002) }
\end{tabular}

All plant and animal wastes or leaf of plants prepared for this purpose could be used as the feed materials for a digester. When feedstock is woody or contains more of lignin, then bio-digestion becomes difficult. Cow and buffalo dung, human excreta, poultry droppings, pig dung, waste materials of plants, cobs, etc can all be used 
Citation: Alemayehu, Y.A. (2015) Enhancement and Optimization Mechanisms of Biogas Production for Rural Household Energy in Developing Countries: A review, Int. Journal of Renewable Energy Development ,4(3), 189-196, http://dx.doi.org/10.14710/ijred.4.3.189-196

P a g e 194

as feed stocks. To obtain an efficient bio-digestion, these feed stocks are combined in proportions (Rai 2004).

The feed stocks for anaerobic digestion vary considerably in composition, homogeneity, fluid dynamics and biodegradability. In intensive animal farming, pig and cow slurries are reported to contain dry matter contents in the range of 3 to $12 \%$. Chicken manure contains 10 to $30 \%$ TS. Some agro-industrial wastes may contain less than $1 \%$ TS, while others contain high TS contents of more than $20 \%$. This results in some substrates being able to be fermented only when mixed with other substrate or diluted (Braun and Wellinger 2002).

Consequently, the need for different substrates such as manure, organic wastes and green plant materials for biogas production is increasing from time to time. For example, the substrates used in Germany are composed of $48 \%$ animal excrement, $26 \%$ organic waste and $26 \%$ renewable green raw materials (Fachagentur 2010). In line with this, studies on the substrates for biogas production such as Cladodes of Opuntia ficus-inica (Elias 2010), food waste (Bilihat 2008), Chat waste (Tesfaye 2007) and Justicia shimperiana (Yitayal et al. 2011) showed that these materials could be used as a substrate either to substitute or supplement cow dung. In addition, maize (Zea mays L.), herbage (Poacae), clover grass (Trifolium), Sudan grass (Sorghum sudanense), fodder beet (Beta vulgaris) and others that serve as energy crops have been studied (Vindis et al. 2009).

It has been reported that the performance of digesters could be considerably improved by means of co-substrate addition and hence increase degradation efficiency and biogas production (Kaparaju et al. 2001). Shivappa et al. (1980) studied different plant wastes like soybean wastes, sunflower wastes, and banana trashes. Up to the fourth month, the total gas production from 1:1 and 1:3 proportions of soybean and cattle dung was more than that of cattle dung alone. Similarly, Rai (2004) recommended that the weight of dung in a dung vegetable mixture should be maintained above 50 \%. Similarly, Anand et al. (1991) carried out an experiment on anaerobic digestion of leaf biomass and water hyacinth for the production of biogas and reported that the decomposition of the leaf biomass and water hyacinth substrates used was rapid, taking 45 and 30 days for the production of 250 and $235 \mathrm{~L}$ biogas per kg of TS, respectively.

In addition, Rajasekaran et al. (1989) studied the anaerobic digestion of Euphorbia tirucally L. They stated that the slurry consisting of $375 \mathrm{~g}$ fresh cow dung, $375 \mathrm{~g}$ of one cm bits of Euphorbia tirucally and $750 \mathrm{~g}$ of water produced 19.2 liters of biogas in nine weeks compared to 16.5 liters produced by cow dung alone. The carbon dioxide content of the biogas was 38 percent from Euphorbia tirucally L. plus cow dung and $35 \%$ from cow dung alone.
Adding human urine is another enhancement mechanism for optimum biogas production. For example, Sau et al. (2014) reported that the rate of biogas production is enhanced at a volume of $150 \mathrm{~mL}$ urine. Thus, a combination of two or more substrates, co-fermentation, will enhance and optimize the degradation properties of the feed stocks and hence increase the methane yield.

\subsection{Pre-treatment of Feed stocks}

Pretreatment provides three benefits for digestion: makes the substrate more accessible to enzymes, minimize lose of organic matter and limiting the formation of inhibitors for production (Liqian et al. 2011; Karaalp 2014).

Plant biomass mainly consists of cellulose, hemicelluloses and lignin which is poorly degraded in anaerobic conditions, and the rate and extent of lignocelluloses utilization is severely limited due to the intense cross-linking of cellulose with hemicelluloses and lignin as these materials form a scum and can easily clog the system. So pre-treatment of the substrate in order to break the polymer chain so that increasing surface area and reduce lignin content is highly important (Fan et al. 1981; Sagagi et al. 2009).

Treatments may be physical, biological or chemical and the most important physical pretreatment of crop biomass is particle size reduction leading to increase in available surface area and release of intracellular components (Palmowski and Muller 1991). According to Badger et al. (1979), mechanical chopping and grinding could provide greater volumes of gas from carbonaceous residues.

Four pre-treatment methods (ultrasonic, chemical, thermal, and thermo-chemical) are studied and suggested for enhancement of biogas production (Almukhtar et al. 2012). It is reported that ultrasonic pretreatment increase methane yield of sugar beet leaf and maize by 43 and $41 \%$, respectively, and chemical pretreatment by 68 and $102 \%$, respectively, and the thermal one increases digestion of straw by $54 \%$ (Liqian et al. 2011). Therefore, before feeding biogas digesters with a substrate pretreatment is needed for enhanced and optimized production. For example, if the substrate is a plant material (leaf), chopping could be needed prior to digestion for the household level.

\subsection{Uniform Feeding and Dilution}

One of the prerequisites of good digestion is uniform feeding of the digesters so that the microorganisms are kept in a relatively constant organic solid concentration at all times. Therefore, the digester must be fed at the same time every day with a balanced feed of the quality and quantity.

All waste materials fed to a biogas plant consist of solid substance, volatile organic matter and nonvolatile matter (fixed solids) and water. During anaerobic fermentation process, volatile solids undergo 
digestion and non-volatile solids remain unaffected (Almukhtar et al. 2012). For optimum gas yield through anaerobic fermentation, normally, 8-10\% TS in feed is required (Rai 2004). This is achieved by making slurry of fresh cattle dung in water in the ratio of $1: 1$. However, if the dung is in dry form, the quantity of water has to be increased accordingly to keep the desired amount and consistency of the input (i.e., ratio could vary from 1:1.25 to even 1:2) (Rai 2004). If the dung is too diluted, the solid particles will settle down into the digester and if it is too thick, the particles impede the flow of the gas formed at the lower part of the digester. In both cases, gas production will be less than optimum (Anonymous 1987).

\subsection{Mixing of the contents of the digester}

According to Rai (2004), since bacteria in the digester have very limited reach to their food, it is necessary that the slurry is properly mixed and bacteria get their food supply. He reported that slight mixing improves the fermentation; however a violent slurry agitation retards the digestion.

Some method of stirring the slurry in a digester is always advantageous. If not stirred, the slurry will tend to settle out and form a hard scum on the surface, which will prevent release of the biogas. This problem is much greater with vegetable waste than with manure, which will tend to remain in suspension and have better contact with the bacteria as a result (Saxon 1998).

\subsection{Inoculation}

The use of a source high in anaerobic microbes (digester effluent for example) to start up an anaerobic system is called inoculation. According to Wilkie (2008), the quality and quantity of inoculums are critical to the performance, time required, and stability of biomethanogenesis during commissioning (startup) or restart of an anaerobic digester. In manures and some wastes the microbes needed for digestion may be already present in the waste in small numbers, albeit sufficient to act as inoculums, and will develop into a fully functional bacterial population if the right conditions are provided (Wilkie 2008).

\section{Conclusion}

This work collects the findings reported in different literatures to be applied in the biogas programs of developing countries, especially for inclusion of the poor people in the rural areas. The programs launched in developing countries could include more households by using different biodegradable plant and waste materials through application of enhancement and optimization mechanisms than depending on cow dung alone as a substrate. Moreover, fulfilling the criteria for the different factors of biogas production would optimize gas yield, minimize time of production, and reduce substrate need and cost.

\section{Acknowledgement}

My special thanks go to Kotebe University College and environmental science, and environmental management staffs for their support and encouragement.

\section{References}

Almukhtar R.S., Asawer A., Alwasiti A.A., Mohammed T., Naser M.T. (2012) Enhancement of Biogas production and organic reduction of sludge by different pre-treatment processes. Iraqi Journal of Chemical and Petroleum Engineering, 13(1): 19- 31

Anand V., Chanakya H.N., Rajan M.G. (1991) Solid phase fermentation of leaf biomass to biogas. Resources Conservation and Recycling $6: 23-33$

Anonymous (1987) Fixed Dome Biogas Plants. A Design, Construction and Operation Manual, TERI, New Delhi, pp 3

Anonymous (2011) Domestic Biogas Newsletter. SNV. Issue 4, http://www.snvworld.org Accessed on 24 February 2013

Badger C.M., Bogue M.J., Stewart D.J. (1979) Biogas production from crops and organic Wastes, New Zealand Journal of Science 22: 1120

Bilihat L. (2007) Contribution and potential of food left over from campus students' cafeteria in biogas energy production, a Master Thesis, Addis Ababa University, pp 34, 66

Botkin D., Keller E. (1995) Environmental science. Earth as a living planet, John Wiley and Sons, New York, pp 345-347

Braun R., Wellinger A. (2002) Potential of co-digestion. IEA Bioenergy, Task 37

Buswell A.M, Sollo F.W. (1948) The mechanism of Methane Fermentation. American Chemical Society 70: 1778-1780

Chipman R., Dzioubinski O. (1999) Trends in Consumption and Production. Household Energy Consumption, DESA discussion paper number 6, pp 3

Chynoweth D.P., Owens J.M., Legrand R. (2001) Renewable methane from anaerobic digestion of biomass. Renewable Energy 22: 1-8

Cunningham M.A., Cunningham W.P., Saigo B.W. (2003) Environmental science. A global concern, $7^{\text {th }}$ edn, McGraw-Hill higher education, USA, pp515-517

Dahlman J., Forst C. (2001) Technologies demonstrated at echo. Floating drum biogas digester; echo, 17391 Durance Rd, North Ft. Myers FL 33917, USA

Elias J. (2010) Study on Renewable Biogas Energy Production from Cladodes of Opuntia ficus-indica, Msc thesis, Addis Ababa University, pp 26-28, 34

Ethiopia's Energy Sector (EES) (2010) Italian development cooperation. http://www.itacaddis.org/italy/index.cfm?fuseaction=basic Accessed on 02 November 2014

European Energy Manager Biogas Preparation Material (EEMBPM) (2006), pp2-5

Fachagentur N. (2010) Responding to the world's growing demand for affordable energy and a Cleaner environment Sustainability for Anaerobic Digestion. http://www.bioenergie-portal.info Accessed on 02 May 2015

Fan L.T, Gharpuray M.M, Lee Y.H. (1981) Evaluation of pretreatments for enzymatic Conversion of agricultural residues. Biotechnology and Bio-energy 11: 29-45

Gannon B. (2005) Biogas Energy Systems. Key Elements of Biogas Energy Systems, Anaerobic digesters. Bio-cycle Conference paper, Germany, pp 3

Getachew E., Sonder K., Heegde F.t. (2006) Report on the feasibility study of a national program for domestic biogas in Ethiopia. SNV Ethiopia, pp 52 
Citation: Alemayehu, Y.A. (2015) Enhancement and Optimization Mechanisms of Biogas Production for Rural Household Energy in Developing Countries: A review, Int. Journal of Renewable Energy Development ,4(3), 189-196, http://dx.doi.org/10.14710/ijred.4.3.189-196

$\mathrm{P}$ a g e 196

Green D., Nagata E., Slotnick J. (2009) World energy assessment. Energy and the Challenge of Sustainability: energy, the environment and health chapter 3, pp 63, 65

Gurung J.B. (1997) Review of Literature on effects of slurry use on crop production. The biogas Support program final report. Kathmandu, Nepal pp 32, 36

Hills DJ. (1979) Effect of C: $N$ ratio on anaerobic digestion of dairy manure. Agricultural Wastes 1: 247-320

Jemmett R. (2006) Methane-biogas production guide; version 1.0, UK pp3-4

Kaparaju P., Luostarinen S., Kalmari E., Kalmari J., Rintala J. (2001) Codigestion of Energy crops and industrial confectionery byproducts with cow manure. Batch scale and Farm-scale Evaluation in Anaerobic Digestion. Anaerobic Conversion for Sustainability. $9^{\text {th }}$ World Congress, Antwerpen - Belgium, September 2-6

Karaalp D., Arslan K., Azbar N. (2014) Enhancement of Biogas Production from Laying Hen Manure via Sonolysis as Pretreatment. J Bioprocess Biotech 4 (6): 179 doi: 10.4172/2155 9821.1000179

Karen A. (1994) Environmental Science, 2 $2^{\text {nd }}$ edn., pp208

Karki, Amrit B.And Krishana M., Guatam (1995) Effect of slurry from anaerobic digestion of organic wastes on crops and vegetables and its residua. Effect on soil. Kathmandu

Liqian W., Mattsson M., Rundstedt J., Karlsson N. (2011) Different Pretreatments to Enhance Biogas Production -A comparison of thermal, chemical and ultrasonic methods. Master Thesis, Halmstad University

Marchaim U. (1992) Biogas processes for sustainable development. Biomass uses following anaerobic digestion. Bulletin FAO Agricultural Services, Rome, 95: 165-193

Marshal A. (2010) Stages of anaerobic Digestion, November. http://www.enwikipedia.org/wiki/file Accessed on 02 November 2014

Mckinney M.L, Schoch R.M. (2003) Environmental Science. Systems and Solutions, Jones and Bartlett: Boston, Massachusetts, London and Singapore, pp 227-232

Nallathambi G.V., Lakshmanaperumalsamy P. (1990) Biogas production potential of parthenium, Biological Wastes 33:311314

NRCS (2005) Conservation Practice Standard. Anaerobic digester in controlled temperature. Number code 366. IA, pp 4-6

Palmowski L. and Muller J. (1999) Influence of the size reduction of organic waste on their anaerobic digestion. In: Mata-Alvarez, J., Cecchi, F. \& Tilche, A. (eds). Proc. $2^{\text {nd }}$ International Symposium on Anaerobic Digestion of Solid Waste: 137-144. IWA Publishing, London

Prasad R.D. (2012) Empirical Study on Factors Affecting Biogas Production. International Scholarly Research Network. Volume 2012, 1-7. ID 136959, doi:10.5402/2012/136959

Quinones T.S., Matthias Plochl M., Budde J., Heiermann M. (2010) Results of batch anaerobic digestion test: effect of enzyme addition. Pp 1-19

Rahmat, B., Priyadi, R., Kuswarini, P. (2014) Effectiveness Of Anaerobic Digestion On Reducing Municipal Waste, International Journal of Scientific \& Technology Research, 3 (3): 98-101

Rai G.D. (2004) Non-conventional energy resources, $2^{\text {nd }}$ edn., Khpu Khanna, India. Pp331-337,369

Rajasekaran P., Swaminthan K., Jayapragasm M. (1989) Biogas production potential of Euphorbia tirucally along with cattle manure. Biological Wastes, 30: 75-77

Reddy N., Amulya K., Wendy A., Kornelis B., David B., Brenda B., Anton E., Jamuna R., Quentin W., Anita K., Mehdi Z. (2004) World Energy Assessment. Energy and Social issues, part I, Chapter 2, pp 40

Rogner H., Fritz B., Maritess C., Andre F., Marc G., David H., Vladimir K. Serguei K., Thierry L., Roberto M., Notstaller R. , Peter O., Martin T. (2004) World energy Assessment. Energy and the Challenge of Sustainability. Energy resources, Chapter 5, pp 136

Sagagi B.S., Garba B., Usman N.S. (2009) Studies on biogas production from fruits and Vegetable waste. Bayero Journal of Pure and Applied Sciences 2(1): 115 - 118
Sau S.K., Manna T.K., Apurba G.A., Nandi P.K. (2014) Enhancement of Biogas Production from Predigested Substrate by Human Urine under Different Thermal Condition. International Journal of Engineering and Innovative Technology (IJEIT) 4 (3):71-77

Saxon J. (1998) Troubled Times. Renewable Energy 2: 519-520

Shivappa S.K., Naharaju H.C., Bhagyaraj D.J., Patil R.B. (1980) Studies on the use of agricultural and animal wastes for biogas production proceedings. RRAI symposium, Punjab Agricultural University, Ludhiana, pp 333-340

Sidhu K.S. (2006) Non-conventional Energy Resources, PEC campus, Chandigarh, pp-6-7

Steffen R., Szolar O., Braun R. (2000) Feedstock for anaerobic digestion. Anaerobic Digestion, making energy and solving modern waste problem, AD-Nett report

Tesfaye N. (2007) Study on anaerobic digestion of chat wastes. MSc Thesis, AddisAbaba University pp-28

UNDP (2004) Over view of World Energy Assessment. Policies and Actions to Promote Energy for Sustainable Development, part VI, pp-68

Velsen V., Lettinga G., and Ottelander D. (1979) Anaerobic digestion of Piggery Waste. Influence of temperature. Netherlands Journal of Agricultural Sciences 27:255-267

Vindis P., Mursec B., Rozman C., Janzekovic M., Cus F. (2009) Mini digester and biogas Production from plant biomass. Journal of Achievements in materials and Manufacturing Engineering 35:191196

Weisman W. (2009) Biogas wrongly ignored as an alternative source of energy: http://special.registerguard.com/csp/cms/sites/web/opinion/2 2324802-47/story.csp. Accessed on 02 December 2014

Wilkie AC. (2008) Bioenergy: Biomethane from biomass, Biowaste and Biofuel, J.Well et al. Washington DC, pp195-199

Yitayal A., Mekibib D., Araya A. (2011) Study on biogas production potential of Justicia shimperiana. MSc Thesis, AddisAbaba University pp-28 